\title{
CLAYTON ACT STATUTE OF LIMITATIONS AND TOLLING BY FRAUDULENT CONCEALMENT
}

THE multiplicity of treble damage actions ${ }^{1}$ brought as a result of the Government's convictions ${ }^{2}$ in 1960 of electrical equipment manufacturers for conspiracies in violation of Section 1 of the Sherman Act $^{3}$ raises the question whether the federal equitable doctrine of fraudulent concealment tolls the four year statute of limitations embodied in Section $4 \mathrm{~B}$ of the Clayton Act. The judicially created doctrine of tolling by fraudulent concealment was originally applied only to bills in equity, but was subsequently extended to actions at law." It provides that a statute of limitations does not begin to run at the time of the commission of the alleged unlawful acts constituting the plaintiff's cause of action where a defendant has engaged in conduct intended to hinder or prevent plaintiff's acquisition of information disclosing the cause of action. ${ }^{0}$ The tolling of the statute of limitations ceases at the time the plaintiff discovers, or should have discovered, the facts upon which his claim is based. Therefore, the plaintiff will have the full period of the statute of limitations, dating from his discovery, in which to bring his cause of action. To avoid the ordinary effect of a statute of limitations a plaintiff must generally establish that the defendant has committed an affirmative act of concealment, ${ }^{7}$ and that reasonable diligence would not have uncovered at an earlier date the facts constituting the plaintiff's claim. ${ }^{8}$ These requirements are not easily met, especially the requirement of reasonable diligence, which is strictly construed..$^{9}$ Because conduct constituting

1. Clayton Act $\S 4,38$ Stat. 731 (1914), 15 U.S.C. $\S 15$ (1958). See notes 29 and 86 infra and accompanying text.

2. For a concise account of the indictments and resultant convictions, sec Application of State of California, 195 F. Supp. 37 (E.D. Pa. 1961).

3. 26 Stat. 209 (1890), 15 U.S.C. $\$ 1$ (1958).

4. 69 Stat. 283 (1955), 15 U.S.C. $\$ 15 \mathrm{~b}$ (1958). The statute reads :

Any action to enforce any cause of action under [the antitrust laws] shall be forever barred unless commenced within four years after the cause of action accrucd. No cause of action barred under existing law on the effective date of this section ... shall be revived by said sections.

5. Bailey v. Glover, 88 U.S. (21 Wall.) 342 (1874).

6. Ibid.; Rosenthal v. Walker, 111 U.S. 185, 190 (1884).

7. Bates v. Preble, 151 U.S. 149 (1894). If a fiduciary relationship is present, silence on the part of the party against whom the cause of action would lie is sufficient concealment. Young v. Howard, 120 F.2d 712 (D.C. Cir. 1941). The concealment must have resulted from the act of the person charged; a fraudulent concealment by an agent will not bind the principal unless the latter induced or had knowledge of the concealment. Bryan v. United States, 99 F.2d 549, 552 (10th Cir. 1938), cert. denied, 305 U.S. 661 (1939).

8. Wood v. Carpenter, 101 U.S. 135 (1879). The plaintiff must fully allege the concealment in order to avoid summary judgment based on the bar of the statute of limitations. The allegation, therefore, to be complete, must set forth the nature of the transaction, the time of discovery, what the discovery is, how the discovery was made and why it was not made sooner. Id. at $140-41$.

9. See Wood v. Carpenter, supra note 8; Moviecolor Ltd. v. Eastman Kodak Co., 288 F.2d 80 (2d Cir.), cert. denied, 368 U.S. 821 (1961). 
fraud, or unlawful conspiracies, generally includes acts intended to conceal the offense from the plaintiff, the doctrine is most frequently invoked in those kinds of claims. The doctrine applies, however, to all claims, regardless of their nature, as long as the requisite element of concealment is present. ${ }^{10}$

Four hundred and eighteen treble damage actions have been brought against the electrical equipment manufacturers in the District Court for the Southern District of New York. ${ }^{11}$ Plaintiffs in these actions alleged combinations or conspiracies dating back to the $1940^{\prime} \mathrm{s}{ }^{12}$ and discovery of the facts upon which their claims are based from the date of the government indictments in $1960 .{ }^{13}$ In answer to the motions of the defendants to strike from plaintiffs' complaints all allegations of damages claimed for any period prior to the four year limit of Section 4B, the plaintiffs contended that Section $4 B$ had been tolled by the defendants' fraudulent concealment. ${ }^{14}$ In Atlantic City Elcc. Co. v. General Elec. Co., ${ }^{15}$ the consolidated hearing on these motions, the district court denied the motions. It held that the decision of the Court of Appeals for the Second Circuit in Moviecolor Ltd. v. Eastman Kodak Co. ${ }^{10}$ was binding upon it and therefore the doctrine of fraudulent concealment was applicable to Section $4 \mathrm{~B} .{ }^{17}$ Thus, if the alleged conspiracies were in fact concealed, the Section $4 \mathrm{~B}$ statute of limitations would not begin to run until 1960.18

Moviecolor was an action on a thirty year old claim to recover treble damages under Section 4 of the Clayton Act for defendants' alleged violation of the antitrust laws in suppressing competition in the manufacture and sale of color still and motion pictures. Acts constituting the alleged violation occurred thirty years before the commencement of the suit. ${ }^{10}$ Prior to January 7, 1956, Section 4B of the Clayton Act was not in force; the various state statutes were used to determine the applicable period of limitations. ${ }^{20}$ The question before the

10. If a fraud is of such a character as to conceal itself, the statute of limitations will be tolled until discovery. Rosenthal v. Walker, 111 U.S. 185, 190 (1884). An integral part of the element of concealment is, however, defendant's scienter. Either the concealing acts of the defendant are of such a nature as to show on their face that the defendant knew they would conceal the cause of action, or, the cause of action itself is of such a nature that, on its face, it indicates the defendant knew the plaintiff could not find out about it.

11. Atlantic City Elec. Co. v. General Elec. Co., 61 Civ. 4258 and Related Cases, S.D. N.Y., July 11, 1962.

12. Id. at 15.

13. Id. at 2 .

14. The motions were consolidated and heard as one by Feinberg, J. Id. at 1-2.

15. 61 Civ. 4258 and Related Cases, S.D.N.Y., July 11, 1962.

16. 288 F.2d 80 (2d Cir.), cert. denied, 368 U.S. 821 (1961).

17. Atlantic City Elec. Co. v. General Elec. Co., 61 Civ. 4258 and Related Cases 9, S.D. N.Y., July 11, 1962.

18. At the same time $\S 4 \mathrm{~B}$ was passed another section was passed which provides for tolling during the lifetime of certain government actions. Section 2, 69 Stat. 283 (1955), 15 U.S.C. $\$ 16(b)$ (1958). Absent the operation of this provision the plaintiffs would, without fraudulent concealment tolling, only be permitted to claim damages for a four year period dating backward from the time of filing the claim.

19. 288 F.2d at 82 .

20. See Chattanooga Foundry \& Pipe Works v. Atlanta, 203 U.S. 390 (1905). 
Moviecolor court, on a motion by defendant for judgment on the pleadings, was whether "the federal rule as to the effect of concealment on the running of a period of limitation applies to an action for treble damages under the Clayton Act even when a state statute is used to measure the period."21 The Second Circuit decided that the applicable state statute of limitations would be tolled if the complaint brought the plaintiff within the federal concealment rule.2 Judge Feinberg, the district court judge in the principal case, however, found that the court in Moviecolor decided an additional issue $:^{23}$

If the doctrine of fraudulent concealment did not apply to the action in Moviecolor and, therefore, did not toll the four year time limit of Section $4 \mathrm{~B}$, then the action was clearly barred since the claim arose almost 30 years before. Only if the doctrine of fraudulent concealment did apply and did toll Section 4B was it necessary for the Court of Appeals to reach the next question: was the action already barred by the state law before the effective date of Section $4 B$ ?

Thus, Judge Feinberg interpreted the Moviecolor decision as first holding that Section $A B$ is tolled by the federal fraudulent concealment doctrine, and then holding that the state statute of limitations could also be tolled by the same doctrine. He reasoned that the Moviecolor court must necessarily have recognized the retroactive applicability of Section $4 \mathrm{~B},{ }^{24}$ and therefore, must have decided the issue of tolling as to Section $4 \mathrm{~B}$ as well as the state statute of limitations. But there is nothing in the Moviecolor decision to indicate that the Second Circuit believed Section $4 B$ was applicable in any manner to the case before it. Rather, the Court of Appeals appeared to reason that, since the alleged unlaw ful acts and the discovery both occurred before the effective date of Section $4 \mathrm{~B},{ }^{25}$ Section $4 \mathrm{~B}$ was not the statute of limitations to which the question of tolling was relevant. The Second Circuit's reasoning was therefore confined to the application of the federal fraudulent concealment doctrine to the New York statute of limitations. ${ }^{26}$ Thus this decision is not precedent for a finding that the doctrine of fraudulent concealment applies to Section $4 \mathrm{~B}$.

21. 288 F.2d at 83.

22. Id. at 84 .

23. Atlantic City Elec. Co. v. General Elec. Co., 61 Civ. 4258 and Related Cases 9, S.D.N.Y., July 11, 1962.

24. See note 4 supra for text of $\S 4 \mathrm{~B}$. It is argued that the first sentence retroactively affects all causes of action accruing prior to $\S 4 B$, no matter how far back. Sce Atluntic City Elec. Co. v. General Elec. Co., supra note 23, at 8, 10.

25. The acts in Moviecolor occurred in 1931, $288 \mathrm{~F} .2 \mathrm{~d}$ at 83 . The discovery was alleged on February 3, 1955, Brief for Plaintiff-Appellant, p. 5, Moviecolor Ltd. v. Eastman Kodak Co., 288 F.2d 80 (2d Cir.), cert. denied, 368 U.S. 821 (1961).

26. This conclusion is supported by the fact that neither the appellant nor the respondent argued the tolling of $\S 4 \mathrm{~B}$ to any great extent in the briefs. See generally, Briefs for Plaintiff-Appellant, Defendant-Respondent, Moviecolor Ltd. v. Eastman Kodak Co., 288 F.2d 80 (2d Cir.), cert. denied, 368 U.S. 821 (1961).

Since the court concluded, however, that "there is no allegation that plaintiff did not know . . . whatever the facts were as to joint action by the defendants," Moviccolor Ltd. v. Eastman Kodak Co., stipra note 25, at 87, the plaintiff's claim of tolling by fraudulent con= cealment failed. It is evident, therefore, that the Moviecolor decision was framed the way it 
The decision in Atlantic City Elec. Co. v. Gencral Elcc. Co., ${ }^{27}$ although the only one seemingly grounded in precedent, ${ }^{28}$ is not the only decision dealing with the question of tolling of Section $4 \mathrm{~B}$ by fraudulent concealment. To date, eight courts have decided this question in treble damage suits, all arising out of the electrical manufacturers' indictments in $1960 . .^{99}$ Of these, five courts, including the Eighth Circuit, decided in favor of tolling, ${ }^{30}$ and three courts have denied its applicability. ${ }^{31}$ Those courts which denied tolling found that the legislative history of Section $4 \mathrm{~B}$ and the absence of an express tolling provision where Congress knew of the possibility of tolling were persuasive evidence of congressional rejection of the fraudulent concealment doctrine. ${ }^{32}$ One court which

was because the court wanted to resolve the vexing problem of whether state statutes of limitations, appended to federally created causes of action, would be tolled by the federal rule of fraudulent concealment, even though the state law provided they should not be so tolled. This court, however, did recognize the existence of $\$ 4 \mathrm{~B}$, and even adverted to the possibility of it being tolled, id. at 84, alluding to colloquys of the 1955 Bill. See note 61 infra and accompanying text. This reference, however, was merely to support the conclusion that the state statutes would be tolled by the federal doctrine.

27. 61 Civ. 4258 and Related Cases, S.D.N.Y., July 11, 1962.

28. See notes 16-23 supra and accompanying text.

29. In addition to Atlantic City Elec. Co. v. General Elec. Co., 61 Civ. 4258 and Related Cases, S.D.N.Y., July 11, 1962, see Public Serv. Co. v. General Elec. Co., No. 4924 Civil and Related Cases, D. N.Mr., July 25, 1962; Kansas City v. Federal Pac. Elec. Co., Civil Nos. 13709-1 and 13710-2, W.D. Mo., August 3, 1962, rev'd, Kansas City v. Federal Pae. Elec. Co., Nos. 17,117 and 17,118, 8th Cir., November 6, 1962; United States v. General Elec. Co., Civil Actions No. 29379 and Related Cases, E.D. Pa., August 21, 1962; Commonwealth Edison Co. v. Allis-Chalmers Mffg. Co., Civil Action No. $61 \mathrm{C} 1277$ and Related Cases, N.D. Ill., August 28, 1962; Public Serv. Co. v. Allen-Bradley Co., Civil Action No. 7349 and Related Cases, D. Col., September 11, 1962; Brigham City Court v. General Elec. Co., Nos. C16-62 and C17-62 through C28-62, D. Utah, September 28, 1962.

There have been two cases not involved in the electrical manufacturers' litigation raising the question of the tolling of $\S 4 \mathrm{~B}$ : Gaetzi v. Carling Brewing Co., $205 \mathrm{~F}$. Supp. 615 (E.D. Mfich. 1962) ; Rinzler v. Westinghouse Elec. Corp., Civil Action No. 7427, N.D. Ga, October 30, 1962.

30. Atlantic City Elec. Co. v. General Elec. Co., supra note 29; United States v. General Elec. Co., supra note 29; Commonwealth Edison Co. v. Allis-Chalmers MIf́g. Co., supra note 29; Kansas City v. Federal Pac. Elec. Co., 8th Cir., supra note 29; Public Serv. Co. v. Allen-Bradley Co., supra note 29. In addition, the court in Gaetzi v. Carling Brewing Co., supra note 29 , decided that although the facts would not permit it tolling as a matter of law would apply.

31. Public Serv. Co. v. General Elec. Co., No. 4924 Civil and Related Cases, D. N.MI., July 25, 1962; Kansas City v. Federal Pac. Elec. Co., Civil Nos. 13709-1 and 13710-2, W.D. Mo., August 3, 1962; Brigham City Court v. General Elec. Co., Nos. C16-62 and C17-62 through C28-62, D. Utah, September 28, 1962. The court in Rinzler v. Westinghouse Elec. Corp., Civil Action No. 7427, N.D. Ga, October 30, 1962, decided against tolling.

32. See note 31 supra. One court, which denied tolling, was partially convinced by the substantive procedural dichotomy, see notes $38-41$ infra and accompanying text, by the burdens which would be placed orr the courts if tolling were granted and by the fact that $\S 4 B$ was primarily concerned with conspiracies. Kansas City v. Federal Pac. Elec. Co., sipra note 31, at 9-12. Apparently Judge Becker felt that, since conspiracies are secretive and concealed by nature, tolling for any conspiracies would result in tolling for all conspiracies, and that this would in effect destroy the statute of limitations for $\$ 1$ violations. See note 85 infra and accompanying text. 
permitted tolling concluded that a showing of contrary congressional intent was necessary to prevent tolling, ${ }^{33}$ and found no contrary intent. ${ }^{84}$ Two courts found the legislative history demonstrative of congressional intent to have tolling, and the Eighth Circuit decided that the nature of a conspiracy is such that Congress must have intended there would be tolling in order to prevent conspiracies escaping the full burden of the antitrust laws. ${ }^{30}$ Despite these differing grounds for decision, there was common ground for agreement: the question of tolling was of great importance and there was a serious need to have the isstre speedily resolved at the highest judicial level.

Until this question is settled the scope of discovery cannot be settled by the trial courts; the pleadings cannot be settled; the potential damages cannot be computed; and settlement negotiations cannot be fully explored in a great number of cases. ${ }^{37}$

These courts utilized three broad bases for decision: the mechanics of statutes of limitations, statutory construction, and legislative history as demonstrative of congressional intent.

The first ground is based upon the argument that Section $4 \mathrm{~B}$ "cannot be suspended on a non-statutory ground [fraudulent concealment] because it is substantive and not procedural in character."38 Statutes of limitations characterized as substantive are those in which the limitations are attached to or directly aimed at a particular right, as when a new right is created and a period is affixed thereto in which to bring an action..$^{30}$ The theory behind not permitting tolling of so-called substantive statutes of limitations is that the "liability and the remedy are . . . to be treated as limitations of the right," ${ }^{40}$ and there-

33. Concluding that Bailey v. Glover, 88 U.S. (21 Wall.) 342 (1874), an early tolling case, demanded this.

34. United States v. General Elec. Co., Civil Actions No. 29379 and Related Cases, E.D. Pa., August 21, 1962.

35. Commonwealth Edison Co. v. Allis-Chalmers Mfg. Co., Civil Action No. 61 C 1277 and Related Cases, N.D. Ill., August 28, 1962; Public Serv. Co. v. Allen-Bradley Co., Civil Action No. 7349 and Related Cases, D. Col., September 11, 1962.

36. Kansas City v. Federal Pac. Elec. Co., Nos. 17,117 and 17,118, p. 24,8 th Cir., November 6, 1962.

37. Kansas City v. Federal Pac. Elec. Co., Civil Nos. 13709-1 and 13710-2, p. 2, W.D. Mo., August 3, 1962. And see, e.g., Atlantic City Elec. Co. v. General Elec. Co., 61 Civ. 4258 and Related Cases 13, S.D.N.Y., July 11, 1962; Commonwealth Edison Co. v. AllisChalmers Mfg. Co., Civil Action No. 61 C 1277 and Related Cases 34, N.D. I11, August 28, 1962.

38. Atlantic City Elec. Co. v. General Elec. Co., 61 Civ. 4258 and Related Cases 8, S.D.N.Y., July 11, 1962.

39. Central Vermont Ry. v. White, 238 U.S. 507, 511 (1915).

40. The Harrisburg, 119 U.S. 199, 214 (1886). This has been a much relied upon dictum for those interested in establishing a substantive-procedural dichotomy in the area of tolling. However, this dictum was not made in reference to the question of tolling, but in reference to the question of a suit, with no excuse for delay, brought after the statutory period lad run. The Court refused to consider what effect an equitable excuse would have had on the delay (i.e., a request for tolling) because "no excuse of any kind has been shown." Ibid. It is improbable that the Court intended its words to be put to the use that the substantive procedural dichotomy has put them. 
fore, when the time limit set by the statute has run, the liability, as well as the remedy, expires and the right is extinguished. One answer to this argument is that the right does not accrue until the prospective plaintiff knows, or should know, that he has a possible cause of action. Moreover, it is not entirely clear that Section $4 \mathrm{~B}$ falls into the category of substantive statutes of limitations, since it was enacted long after the rights to which it applies were created.11 Even more important, however, the distinction between substantive and procedural statutes of limitations is a tenuous one ${ }^{22}$ and the argument that the right is extinguished conclusory. As the Supreme Court has stated in an action involving the waiver of a so-called substantive statute of limitations:

Origin of the right is not per se conclusive whether the limitation of time "extinguishes" it or "merely bars the remedy" with the accepted alternative consequences respecting waiver. Source is merely evidentiary, with other factors, of legislative intent whether the right shall be enforceable in any event after the prescribed time ....43

The question, therefore, is ultimately one of legislative intent; whether the legislature, when it created the right and limited it temporally, intended the cause of action to accrue even though the prospective plaintiff neither knew, nor could be held to have known it existed.

Construction of the statute to determine whether Section $4 \mathrm{~B}$ is tolled by fraudulent concealment is equally indeterminate. Arguably, the language of the statute suggests a negative answer: Section $4 \mathrm{~B}$ is silent on the question of tolling; Section 5(b) ${ }^{44}$ provides for tolling while a government action is pending. Therefore, it might be inferred that Congress intended tolling under Section 5 (b) to be the only tolling permitted. This inference is reinforced by the fact that statutes have been written which expressly provide for tolling until discovery of the facts which constitute the claim. Thus, Congress has, where it felt it desirable, written tolling provisions analogous to the doctrine of fraudulent concealment in federal statutes. ${ }^{45}$ However, the Supreme Court stated in Holnu-

41. The "substantive" rule, however, may be applicable even though the period of limitation is provided in a different, subsequent legislative act provided the subsequent act is directed to the legislatively created cause of action. See Davis v. Afills, 194 U.S. 451 (1904).

42. The rule removing "substantive" statutes of limitation had its carliest and widest application in the field of conflicts of laws in cases involving suits on causes of action created by a statute of a state other than the forum. Kansas City v. Federal Pac. Elec. Co., Civil Nos. 13709-1 and 13710-2, p. 9, W.D. Mo., August 3, 1962. See Restatearenit, Cosifuct of LAws $\S 605$ (1935). The distinction, whatever its antecedents, is vitiated, however, by the fact that the test to determine whether a statute of limitations is substantive or prosedural is not at all clear. Bournias v. Atlantic Mlaritime Co., 220 F.2d 152, 155-56 (2d Cir. 1955). See Cook, "Substance" and "Procedure" in the Conffict of Laus, 42 Y YIE L.J. 333 (1933) ; Comment, The Statute of Limsitations and the Conflict of Lau's, 28 YALE L.J. 492 (1919).

43. Midstate Horticultural Co. v. Pennsylvania R.R., 320 U.S. 356, 360 (1943).

44. 69 Stat. 283 (1955), 15 U.S.C. \& 16b (1958). See note 18 stpra.

45. Statutes expressly calling for accrual at discovery: The Tariff Act of 1930 \$ 621, 46 Stat. 758, as amended, 49 Stat. 527 (1935), 19 U.S.C. \$ 1621 (1958); The Securities Exchange Act of $1933 \S 13$, 48 Stat. 84, as amended, § 207(a), 48 Stat. 908 (1934), 15 
berg v. Armbrecht, a case involving fraudulent concealment tolling of the Federal Farm Loan Act statute of limitations, that "[ $t$ ]his equitable doctrine is read into every federal statute of limitation."46 Although this was stated in dictum, it has often been relied upon by federal courts. ${ }^{47}$ Given a presumption of legislative notice of judicial interpretations, ${ }^{48}$ the absence of an explicit tolling provision in Section 4B is not determinative of the issue.

Nor, however, is the dictum in Holmberg v. Armbrecht. ${ }^{40}$ Clearly the fraudulent concealment rule was not intended to be read into statutes in which Con* gress explicitly had denied its application. More generally, the Court, both before and since Holmberg v. Armbrecht ${ }^{50}$ has applied a particular equitable tolling doctrine only in the absence of evidence that Congress did not intend it to apply (or refused to apply one where the evidence did demonstrate congressional rejection). ${ }^{51}$ Since equitable tolling doctrines rely upon an act by the defendant which forestalls a plaintiff from bringing an action, ${ }^{52}$ this experience is readily applicable to the specific tolling doctrine of fraudulent concealment. Therefore, it is reasonable to conclude that Holmberg v. Armbrccht tos does not demand that the equitable doctrine of tolling by fraudulent concealment be

U.S.C. $\$ 77 \mathrm{~m}$ (1958); The Securities Exchange Act of 1934 § $18 \mathrm{c}$, 48 Stat. 898, 15 U.S.C. $\S 78 \mathrm{r}$ (c) (1958); The Trust Indenture Act of 1939 \$ 323, 53 Stat. 1176, 15 U.S.C. $\$ 77 w w w$ (a) (1958) ; Act of March 6, 1946, ch. 48, § 3, 60 Stat. 31-32, 31 U.S.C. $\S 131$ (1958) (United States may bring action on alteration of checks and warrants) ; The Federal Deposit Insurance Act of $1950 \S 7 \mathrm{~g}, 64$ Stat. 878, 12 U.S.C. § 1817(g) (1958).

46. 327 U.S. 392, 397 (1946) (per Frankfurter, J.).

47. E.g., Moviecolor Ltd. v. Eastman Kodak Co., 288 F.2d 80, 82 (2d Cir.), ccrt. dcnied, 368 U.S. 821 (1961) ; Hicks v. United States Radiator Co., 127 F. Supp. 429, 430-31 (E.D. Mich. 1955) ; Grossman v. Young, 72 F. Supp. 375, 379 (S.D.N.Y. 1947).

48. As when Congress re-enacts a legislative provision, it is perstasive evidence that Congress has adopted that body of judicial construction. Missouri v. Ross, 299 U.S. 72, 74 (1936).

49. 327 U.S. 392 (1946).

50. Ibid.

51. Thus, for example, in cases before Holmberg $v$. Armbrecht involving tolling by a general demurrer, A.J. Philips Co. v. Grand Trunk Western Ry., 236 U.S. 662 (1915) (Interstate Commerce Act), self concealing fraud, Exploration Co. Ltd. v. United States, 247 U.S. 435 (1918) (act for annulment of land patents), see also United States v. Diamond Coal \& Coke Co., 255 U.S. 323 (1921), and waiver, Midstate Horticultural Co. v. Pennsylvania R.R., 320 U.S. 356 (1943) (Interstate Commerce Act), and in cases after Holmbcry v. Armbrecht tolling by administrative action, Unexcelled Chemical Corp. v. United States, 345 U.S. 59 (1953) (Walsh-Healey Act) and active misrepresentation, Glus v. Brooklyn Eastern District Terminal, 359 U.S. 231 (1959) (FELA), the Court concluded that mere mechanical application or denial of equitable tolling doctrines was not warranted, but, that the language and history of a particular statute must always control.

52. E.g., waiver, in which the defendant agrees not to plead the bar of the statute of limitations should the plaintiff bring suit, Midstate Horticultural Co. v. Pennsylvania R.R., supra note 51, self-concealing fraud, in which the defendant commits an act such that the plaintiff could not discover it, Exploration Co. Ltd. v. United States, supra note 51, or active misrepresentation, in which the defendant tells the plaintiff he will have a period of years greater than the statutory period in which to bring his claim. Glus v. Brooklyn Easte ern District Terminal, supra note 51.

53. 327 U.S. 392 (1946). 
read into a statute of limitations whose legislative history demonstrates a rejection of the doctrine.

The legislative history relating to the question of tolling Section $4 \mathrm{~B}$, although complex and at places unclear, does not demonstrate a rejection of the fraudulent concealment doctrine. ${ }^{54}$ Until 1949 no attempt had been made to amend the antitrust laws to provide for a federally created statute of limitations. ${ }^{65}$ Four bills were introduced in the 81 st Congress, 56 three of which contained provisions for tolling in conspiracy cases, subject to the requirement of due diligence, until the discovery of the conspiracy. ${ }^{57}$ These proposals were not well received, and none came to a full vote in both the House and Senate. ${ }^{\text {ts }}$ Congressional rejection of the 1949 provision has been viewed by three courts as conclusive evi-

54. See note 58 infra.

55. See Hearings on S. 1910 Before a Subcommittee of the Senate Committec on the Judiciary, 81st Cong., 1st Sess. 12 (1949) [hereinafter referred to as Senate Hearings] (remarks of Senator Donnell and John C. Stedman; Chief, Legislation and Clearance Seetion, Antitrust Division, Department of Justice).

56. S. 1910, H.R. 4985, 81st Cong., 1st Sess. (1949) (both with the tolling provision); H.R. 7905, 81st Cong., 2d Sess. (1950) (with the tolling provision) and H.R. 8763, 81st Cong., 2d Sess. (1950).

57. Any action ... may be instituted within six years after the accrual of the cause of action hereunder; or, in the case of ... conspiracy ... within six years after the discovery by the plaintiff of the ... conspiracy, if the plaintiff has exercised due diligence....

Senate Hearings 1 . The tolling provisions in the remaining two bills are substantially the same.

58. S. 1910, 81st Cong., 1st Sess. (1949) and H.R. 7905, 81st Cong., 2d Sess. (1950) had hearings, the other two did not. The tolling provisions of these two bills are hereinafter referred to as the "1949 provision."

The hearings on two of the bills reveal statements condemning the tolling as too harsh on defendants and encouraging excessive litigation. See, c.g., Hearings on H.R. 7905 Before a Subcommittee of the House Committee on the Judiciary, 81st Cong., 2d Sess., scr. 14, pt. 5, at 89 (statement of the United States Chamber of Commerce), 92 (statement of the Association of the Bar of City of New York), 95 (statement of the American Bar Association) 1950 (hereinafter referred to as House Hearings); Scnatc Hearisgs 42 (statement of Louis Nizer, attorney). The Justice Department and FTC both failed to makse statements supporting the provision in the first bill, although the Justice Department, noting the difficulties inherent in discovering conspiracies, did support the tolling provision of the second bill. See Senate Hearings 10-15 (statement of John C. Stedman, Chief, Legislative and Clearance Section, Antitrust Division, Department of Justice), 15-16 (statement of James W. Cassedy, Associate General Counsel, Federal Trade Commission); Housc Hearings 65 . In addition to the four bills in the 81st Congress, there were three in the 82d Congress (H.R. 3408, H.R. 1323, and H.R. 1986, 82d Cong., 1st Sess. [1951]) and one in the 83d Congress (H.R. 467, 83d Cong., 1st Sess. [1953]) dealing with a statute of limitation for the antitrust laws. Only one of these bills adverted to tolling (H.R. 1986, 82d Cong., 1st Sess. [1951]), the same tolling provision as S. 1910, 81st Cong., 1st Sess. (1949). Only one of these bills (H.R. 3408, 82d Cong., 1st Sess. [1951]), had hearings and none yielded committee reports. The bill which became the 1955 amendment was H.R. 4954, 84th Cong., 1st Sess. (1955). There were no hearings held on this bill; the House and Senate reports on the bill utilized the aforementioned House and Senate Hearings supro, notes 38, 41. See generally S. REP. No. 619, 84th Cong., 1st Sess. (1955) ; H. REP. No. 422, 84th Cong., 1st Sess. (1955). 
dence of legislative intent on the question of tolling by fraudulent concealment. But legislative inaction is not a reliable indication of congressional intent. ${ }^{10}$ In addition, arguably the 1949 amendment provision was different from the fratdulent concealment doctrine in at least two respects. First, the rejected provision called for tolling in all conspiracy cases until discovery of the conspiracy whether or not there were any positive acts of concealment on the part of the defendant. $^{61}$ The fraudulent concealment doctrine, on the other hand, does not provide for tolling in all conspiracy cases. In addition to the obvious case of a conspiracy concealed by affirmative acts of the defendant, there are conspiracies recognized by the courts as self-concealing in nature. ${ }^{62}$ Although it has been held that selfconcealing conspiracies are subsumed under the doctrine of fraudulent concealment, ${ }^{63}$ the 1949 provision and the fraudulent concealment doctrine would, nevertheless, reach different results in the situation where the acts were found to be conspiratorial but neither self-concealing in nature nor affirmatively concealed (e.g., a trade organization which makes public its goals and practices). To the extent that such conspiracies exist, tolling would occur in more cases under the 1949 provision than under the fraudulent concealment doctrine. This distinction, however, is likely to be of little practical significance, applying to situations-non-self-concealing conspiratorial acts constituting causes of action under the antitrust laws-which would arise infrequently. If susceptible to possible challenge under the antitrust laws, business conspiracies are likely to be affirmatively concealed by the parties. Furthermore, a showing of plaintiff's due diligence would undoubtedly be a prerequisite to tolling under the 1949 provision even though affirmative acts of concealment need not necessarily be shown. ${ }^{64}$ And it is unlikely that the plaintiff would be able to carry the burden of proving due diligence where the conspiracy is neither self-concealing nor concealed by affirmative acts. In those situations, the plaintiff prestumably knows that some act of the defendant has caused him injury. Knowing of the injury, plaintiff would be held by the due diligence requirement to inquire into those acts of the defendant which had injured him. ${ }^{65}$ Since concealment would be absent, and the plaintiff would be held to know or have the duty of ascertaining those non-concealed acts of the defendant which gave rise to the cause of action, tolling would ordinarily be unavailable in such cases. Consequently, this apparent difference between the 1949 provision and the equitable doctrine of

59. See note 31 supra.

60. See Shapiro v. United States, 335 U.S. 1, 44 (1948) (Frankfurter, J., dissenting).

61. See note 57 sipra.

62. American Tobacco Co. v. People's Tobacco Co., 204 Fed. 58, 60 (5th Cir. 1913). "Self concealment' of a conspiracy sufficient to toll the statute of limitations refers to activities in furtherance of the conspiracy which by their nature defy detection." Gaetzi v. Carling Brewing Co., 205 F. Supp. 615, 623 (E.D. Mich. 1962). See also Moviecolor Ltt. v. Eastman Kodak Co., 288 F.2d 80, 87 (2d Cir.), cert. denied, 368 U.S. 821 (1961).

63. Ibid.

64. See note 57 supra and accompanying text.

65. Cf. Burnam Chem. Co. v. Borax Consol. Ltd., 170 F.2d 196, 209 (9th Cir. 1950), cert. denied, 340 U.S. 943 (1951). 
fraudulent concealment has no practical significance. But some Congressmen may have considered this apparent difference a real one and rejected the 1949 provision because it would be too harsh on certain defendants and would encourage excessive litigation. ${ }^{60}$ Other Congressmen, either not aware of the apparent difference or aware that it was not a real one, may have felt the amendment superfluous, since the existence of Holmberg $v$. Armbrecht ${ }^{07}$ suggests that the tolling embodied in the 1949 provision was to be read into every federal statute of limitations. ${ }^{68}$

The second apparent difference is that the 1949 provision was concerned with tolling only in conspiracy cases, ${ }^{69}$ while the fraudulent concealment doctrine applies tolling to non-conspiracy as well as conspiracy cases. In conspiracy cases, the acts constituting the cause of action will often be sufficiently self-concealing ${ }^{70}$ to validate tolling under the fraudulent concealment doctrine, while a non-conspiracy situation will probably require an act of concealment in addition to the act giving rise to the cause of action. Since non-conspiratorial acts are ordinarily easier to discover than conspiracies, one might want to penalize a defendant more severely for a further act designed to conceal violations of the antitrust laws. Thus, it would not be inconceivable for a legislature to reject a provision calling for tolling in conspiracy cases until discovery of the conspiracy and still endorse the doctrine of fraudulent concealment as to all other antitrust violations. In the perspective of the antitrust laws, however, the causes most obnoxious to the expressed policy have been denominated illegal per se, and certain conspiracies are included in this category of violations. ${ }^{71}$ It is difficult to conclude that Congress, without any clear statement of intent, would have decided to treat illegal per se conspiratorial price fixing ${ }^{72}$ more favorably than other less anathemized offenses. More importantly, those who favored fraudulent concealment tolling in both conspiracy and non-conspiracy cases may have been concerned lest the 1949 provision, if enacted, be interpreted as indicating congressional intent to limit tolling solely to conspiracy cases. ${ }^{73}$

66. See note 58 supra (statement of United States Chamber of Commerce, Association of the Bar of the City of New York and Louis Nizer).

67. 327 U.S. 392 (1946).

68. Id. at 397.

69. See note 57 supra.

70. See note 62 supra and accompanying text.

71. See, e.g., United States v. Socony-Vacuum Oil Co., 310 U.S. 150, 224 n.59 (1940) (conspiratorial price fixing); Associated Press v. United States, 326 U.S. 1 (1945) (concerted refusal to deal) ; International Salt Co. v. United States, 332 U.S. 457 (1947) (tying non-patented product to patented product).

72. E.g., United States v. Socony Vacuum Oil Co., supra note 71; Appalachian Coals, Inc. v. United States, 288 U.S. 344 (1933); United States v. Trenton: Potteries Co., 273 U.S. 392 (1927).

73. Others may have rejected the provision because of the manner in which the bill arose. The tolling amendment was urged at the behest of a private citizen. The plaintiff in Burnam Chem. Co. v. Borax Consol., Itd., 170 F.2d 569 (9th Cir.), cert. denied, 336 U.S. 924 (1948) (his cause of action held barred because, according to the applicable state fraudulent concealment rule, he should have known of his cause of action long enough for 
The highly speculative nature of the inferences derivable from the congressional rejection of the 1949 provision suggest the difficulties inherent in relying on that rejection as conclusive of legislative intent. The only conclusion a reading of that legislative history clearly supports is the descriptive statement that Congress, in 1949, rejected tolling in conspiracy cases until discovery of the conspiracy.

The 1955 proposal for a federal statute of limitations governing antitrust cases had no tolling provision and no new hearings were held.74 $A$ series of ambiguous statements relating to tolling were made, however, on the floor of the House. ${ }^{75}$ Although directed at tolling in conspiracy cases similar to that proposed in 1949, rather than the judicial doctrine of tolling by fraudulent concealment, these statements seem to imply that Congress assumed a tolling provision would be read into Section $4 \mathrm{~B}$. Since those Congressmen involved in the colloquies were consistent proponents ${ }^{76}$ of express tolling provisions of the type rejected by Congress in 1949, their statements should be read in the light of their continuing interest in having such a provision read into the bill. Thus, an answer to the question of tolling cannot be derived from the legislative background of Section 4B in 1955. In the absence of assistance from the legislative history of the 1955 act, it seems totally unwarranted to conclude, on the basis of congressional inaction in 1949, that in 1955, a different Congress, in accepting a bill which did not mention tolling by fraudulent concealment, rejected the application of the principle enunciated in Holmberg $v$. Armbrecht ${ }^{77}$ to Section 4B. Since this principle holds that in the absence of contrary legislative intent, the doctrine of tolling by fraudulent concealment is to be read into every federal statute of limitations, it is clear that, if followed, Section $4 \mathrm{~B}$ is tolled whenever a defendant affirmatively conceals the facts constituting a violation of the antitrust laws and the plaintiff has fulfilled the requirement of due diligence.

the applicable state statute of limitations to have run:) attempted to have himself legislated back into court. He thought a provision calling for tolling until discovery of the conspiracy would have revived his cause of action. However, since it had already been held that he should have known of his cause of action, which was the conspiracy which injurcd him, passage of the amendment would not have afforded him relief. Thus, the peculiar circumstances which gave rise to the provision suggest two more grounds for congressional rejection: (1) it was a mistaken attempt to supplement Holmberg v. Armbrecht, and (2) the provision was intended to benefit but one plaintiff. See generally Housc and Scratc Hearings, notes 55 \& 58 supra.

74. See note 58 stipra.

75. See, e.g., 101 Cong. REC. 5129 (1955) (Mr. Celler: "In the case of conspiracy or fraud, the statute only runs from the time of discovery.") Congressman Celler made substantially the same statement twice during later discussion. 101 CoNG. Rec. at 5130 (remarks of Congressmen Patman, Keating and Celler) and at 5132-33 (remarks of Congressmen Patman and Celler).

76. See, e.g., Hearings on H.R. 3408 Before a Subcomnittec of the Honse Committce on the Iudiciary, 82d Cong., 1st Sess., ser. 1, pt. 3, at 100 (remarks of Congressman Patman), 105 (amendment suggested by Congressman Patman) (1951).

77. 327 U.S. 392 (1946). 
But reliance on this principle, which has its origin in dictum, albeit dictum of the Supreme Court, seems to be a rather mechanical way to decide an important issue of policy under the antitrust laws. To be sure, it is desirable to have a doctrine which will secure a plaintiff from loss of his cause of action because of fraudulent self-serving acts of a defendant. But a broad application of the doctrine to an array of heterogeneous statutes involving differing policy schemes and expressing a balance of numerous considerations may not be warranted. Such an automatic application may upset the balance achieved in any one statute. ${ }^{78}$ Therefore, it is arguable that the rule enunciated in Holmberg $v$. Armbrecht ${ }^{79}$ should not decide the issue of tolling of all federal statutes of limitations, and that the courts should weigh the effects of the application of the doctrine in regard to the policy scheme of the particular statute in question. Judicious use of a flexible equitable doctrine presupposes a weighing of the interests affected by its application.

Such an examination in respect to the antitrust laws or to particular provisions of these laws is no easy task. But it is one courts must undertake unless they are to continue to decide the tolling issue on the inconclusive grounds set out above or on the basis of a dictum whose implications were never considered in the context of the antitrust laws. The following is not an attempt to resolve the question, but to set out some of the factors a court should consider in deciding this issue in respect to Section $4 \mathrm{~B}$.

Treble damage actions in the framework of the antitrust laws are intended to compensate persons injured by proscribed business practices ${ }^{80}$ and to deter persons from engaging in such activities. ${ }^{81}$ The significance of the private treble damage suit in the enforcement mechanism of the antitrust laws has often been noted ;82 private treble damage plaintiffs have been characterized as "allies of the government in enforcing the antitrust laws." $\$ 3$ Conspiracies which violate the antitrust laws are frequently concealed by potential defendants or are selfconcealing in nature $;^{84}$ thus it may be extremely difficult for potential treble damage plaintiffs to discover violations within the statutory four year period in which suit must be commenced. Thus, it seems clear that denying application of the doctrine would greatly reduce potential liability and thus the deterrent

78. As in the Interstate Commerce Act where Congress has demonstrated an intention to have uniformity the central theme of the statutory scheme. See Philips v. Grant Trunk: Ry., 236 U.S. 662 (1915).

79. 327 U.S. 392 (1946).

80. United States v. National City Lines, 334 U.S. 573, 581 (1948).

81. CIR v. Obear-Nester Glass Co., 217 F.2d 56, 61 (7th Cir. 1954), cert. denicd, 348 U.S. 982 (1955).

82. E.g., Bicks, The Department of Justice and Prizate Treble Damage Actions, 4 Antrtrust Bull. 5 (1959); Loevinger, Prizate Action-The Sirongest Pillar of Antitrust, 3 AntrTRust BULI. 167 (1958); Wham, Autitrust Treble-Damage Suits: The Government's Chief Aid in Enforcement, 40 A.B.A.J. 1061 (1954).

83. 51 CoNG. Rec. 16319 (1914) (remarks of Congressman Floyd). For a discussion of treble damage actions in a different context, see Note, Discouragement of Prizale Trcble Damage Suits Through a Simple Refusal to Deal, 71 Y ALE L.J. 1565 (1962).

84. See note 62 supra and accompanying text. 
effect of the treble damage provisions of the antitrust laws. Furthermore, it should be recognized that application of the doctrine would not necessarily give rise to excessive litigation of stale claims. For plaintiffs have had enormous difficulty in the past proving claims of fraudulent concealment. ${ }^{\text {gu }}$ Consequently, the decision that fraudulent concealment is available to toll Section 4B does not demand that there would be widespread tolling.

On the other hand, the instant case illustrates some of the detrimental effects application of the doctrine to Section $4 \mathrm{~B}$ may have. In this litigation, there are close to 1,800 suits, ${ }^{86}$ each with multiple claimants, multiple defendants and multiple claims, running back at least as far as twenty years. ${ }^{87}$ The complexity of administrative problems facing the court from sheer numbers, the possibility of devastating liability severely injuring an entire industry, as well as affecting stock and other markets, and the adverse effects tolling might have on the nummber of out of court settlements are all factors which may indicate that tolling in the antitrust laws would not be desirable. A court could conclude that the likelihood of these factors in antitrust suits is so great that the doctrine should not be read into Section 4B. If a court is convinced that tolling Section $4 \mathrm{~B}$ is likely to have undesirable economic repercussions and confound the operation of the courts, it could decide to reject tolling for liaiblity purposes, thereby reducing the probability of excessively burdensome liability as well as multiplicity of claims.

The possibility of applying the tolling doctrine for some purposes and not for others also should not be overlooked. Thus, for example, tolling may be utilized to alleviate problems plaintiffs may face in making discovery, ${ }^{88}$ although the doctrine is rejected as to the liability of antitrust defendants. Discovery for complex antitrust litigation may be consolidated in a nationwide discovery pro* ceeding, as in the instant case, ${ }^{80}$ thereby reducing the burden of repetitive and inefficient discovery. Where plaintiffs demonstrate that if denied discovery beyond the four year period they would be unable to substantiate their damage claim within the four year period, a court could decide that tolling for discovery

85. See, e.g., Moviecolor Ltd. v. Eastman Kodak Co., 288 F.2d 80, 87 (2d Cir.), ccrt. denied, 368 U.S. 821 (1961) ; Suckow Borax Mines Consol. v. Borax Consol., 185 F.2d 1\%(, 209 (9th Cir. 1950), cert. denied, 340 U.S. 943 (1951) ; Burnam Chem. Co. v. Borax Contsol., 170 F.2d 569, 577 (9th Cir.), cert. denied, 336 U.S. 924 (1948); Gaetzi v. Carling Brewing Co., 205 F. Supp. 615, 623 (E.D. Mich. 1962) ; Zimmerer v. General Elcc. Co., 120 F. Supp. 690, 693 (D. Conn. 1954).

Allegations are read with close particularity; due diligence is strictly construcd and not easily found. See Wood v. Carpenter, 101 U.S. 135, 140 (1879) ; Moviecolor Ltd. v. Tastman Kodak Co., supra.

86. Atlantic City Elec. Co. v. General Elec. Co., 61 Civ. 4258 and Related Cases 5, S.D.N.Y., July 11, 1962.

87. Id. at 15 .

88. Plaintiffs ordinarily would have stringent proof requirements to be able to get certain types of discovery. See FED. R. Crv. P. 34. The courts could relieve this stringency by the suggestion in the text which could act as a conclusive showing of relevancy.

89. Kansas City v. Federal Pac. Elec. Co., Civil Nos. 13709-1 and 13710-2, p. 2, W.D. Mo., August 3, 1962. 
purposes only would neither inconvenience the courts nor burden the defendants unduly. Whatever choice is eventually made, however, it seems clear that a consideration of the above and other factors is a preferable basis for decision of the applicability of the fraudulent concealment doctrine to Section 4B than the unquestioning application of the dictum in Holmberg v. Armbrecht ${ }^{80}$ or the questionable grounds utilized by the courts to date.

90. 327 U.S. 392 (1946). 